\title{
OBJECTIVELY MEASURED WEEKLY PHYSICAL ACTIVITY AMONG ADOLESCENT BOYS AND ITS RELATION TO HEALTH-RELATED PHYSICAL FITNESS
}

\author{
Edita Maciulevičienė, Rita Sadzevičienė, Renata Rutkauskaitė \\ Lithuanian Sports University, Kaunas, Lithuania
}

\begin{abstract}
Research background and hypothesis. The objective methods of measuring physical activity (PA) are used more and more widely in various types of research. However, in Lithuania there is a lack of such studies with adolescents. Thus, we conducted a pilot study to objectively measure boys' PA and to develop a more accurate PA assessment methodology in Lithuania.

The purpose of this study was to analyse the objectively measured adolescent boys' weekly physical activity and its relation to their body composition and physical fitness.

Research methods. The participants of this study were 104 healthy adolescent boys. Physical activity of schoolboys was measured using actigraphs (Tri-axis ActiTrainer Activity Monitors). The level of the intensity of physical activity was determined by calculating energy consumption in MET's. Low PA(LPA) equals up to 3 MET's, moderate PA (MPA) - 3-6 MET's, and vigorous PA (VPA) - 8 or more METs. Based on the frequency of VPA and MPA per week, the participants of this study were divided into physical activity groups. For health-related physical fitness assessment the following tests were used: body composition (using TANITA Body Analyser, TBF-300); flexibility (sit and reach test, Eurofitas, 2002), power (vertical jump was measured using a jump parameter gauge (SBM-1), muscular strength and endurance (modified push-up test (Suni et al., 1994)).

Research results. All of the schoolboys demonstrated LPA on each day of the assessment. MPA on each day was experienced by $59.6 \%$ of the boys. No participants achieved VPA. The most frequent MPA and VPA were observed 5-7 and 1-3 days per week, respectively. Results of body composition indicated that boys experiencing VPA had lower body fat mass compared to those who experienced only MPA and LPA $(p<0.05)$. Analysis of physical fitness results indicated that boys who experienced VPA were better muscular in strength and endurance test $(p<0.05)$, but results of high jump and sit and reach test were not significantly different.

Discussion and conclusion. Boys who experienced VPA at least for 3 days/week demonstrated better muscular strength and endurance results and had lower body fat content $(\%)(p<0.05)$. For boys who did not experience MPA at least for 6 days/week, the total amount of weekly physical activity decreased and they could not produce better results in strength and endurance test $(\mathrm{p}<0.05)$. Better results of boys' muscular strength and endurance were significantly related to their body lower BMI $(r=0.279 ; \mathrm{p}<0.05)$ and fat mass $(r=0.387 ; \mathrm{p}<0.01)$.
\end{abstract}

Keywords: physical activity, MET's, actigraphs.

\section{INTRODUCTION}

$\mathrm{P}$ hysical activity is suggested to be an essential part of everyday life, especially during growth and rapid development of schoolaged children. The benefits of PA are numerous: it has a positive effect on the prevention of various diseases in schoolchildren (Rankinen, Bouchard,
2002) and on their cognitive development (Burdette, Whitaker, 2005), it increases self-esteem and controls the levels of anxiety and stress, normalizes the state of mind (Burdette, Whitaker, 2005), and certainly it affects the level of physical fitness (PF) (Dencker et al., 2006). It is suggested that physical 
fitness is an integrated dimension of most, if not all, functions of the organism related with physical activity (Ortega et al., 2008).

Physical activity plays an important role in the prevention of becoming overweight and obese in children and adolescents, reducing the risk of obesity and positively influencing health status in adulthood (Matton et al., 2006). Puberty and the following adolescent period are acknowledged as particularly vulnerable times for the development of obesity due to sexual maturation and, in many individuals, a concomitant reduction in physical activity (Hills et al., 2011). The prevalence of obesity among children and adolescents has increased dramatically since the mid-1970 s in many countries throughout the world (Lobstein et al., 2004).

Current physical activity recommendations state that adolescents should be active for a total of at least an hour a day, children at the beginning of school age - considerably more (The National Guidelines on Physical Activity for Ireland, 2009). Despite all these health benefits many children all over the World do not meet these guidelines (Malina, Katzmarzyk, 2006; Samdal et al., 2007).

Most physical activity data are available for children and adolescents, 10 years of age and older, and are based largely on questionnaires and interviews. Physical activity is very difficult to measure and there is no gold standard measurement for daily physical activity. There are more than 30 different methods of assessing physical activity. Some of them have been identified, but validity, objectivity and reliability of these methods have not been enough established with children and adolescents (Sirard, Pate, 2001; Trost, 2001). M. Dencker and L. B. Andersen (2008) presented an excellent review of the use of accelerometers for the measurement of daily physical activity in children. In recent years, accelerometers (Actigraph) have gained popularity as an objective measurement device for daily physical activity (Ottevaere et al., 2011). The ActiTrainer is the first and most common tool for accurate monitoring of physical activity during 24-hour and longer period, but the data of the duration, intensity and scope of children's and adolescent's every day activity, according to WHO (World Health Organization) recommendations are insufficient. Moreover, there is a lot of research devoted to interrelations of not objectively measured physical activity and physical fitness. So, the purpose of this study was to analyse the objectively measured adolescent boys' weekly physical activity and its relation to health-related physical fitness.

\section{RESEARCH METHODS}

The participants of this study were 104 healthy adolescent boys (15.3 \pm 0.06 years of age; $63.0 \pm$ $1.32 \mathrm{~kg}$ of weight, and $175.8 \pm 0.78 \mathrm{~cm}$ in height). The boys were selected using cluster screening, i.e. the schools were randomly selected, and their $9^{\text {th }}$ grade schoolboys were randomly invited to take part in the assessment. Initially, the data was collected from 112 boys, but 8 cases were withdrawn from the final analysis due to incomplete results (not all participants performed physical fitness tests) and failure to wear the monitor throughout the defined period of time. All participants and their parents or legal guardians gave an informed consent to take part in the study. The time and location of the measurements to be taken were agreed upon in advance with the administration of the schools as well as teachers. The volunteers were free to withdraw from the study at any time without any consequences.

Assessment of physical activity (PA). The physical activity of schoolboys was measured using actigraphs (Tri-axis ActiTrainer Activity Monitors). The level of the intensity of physical activity was determined by calculating energy consumption in METs; bouts of physical activity (PA) had to last for at least 10 minutes without interruptions. Low PA (LPA) equals up to 3 MET's, moderate PA (MPA) - 3-6 MET's, and vigorous PA (VPA) -8 or more MET's. Based on the frequency of vigorous (VPA) and moderate physical activity (MPA) per week, the participants of this study were divided into physical activity groups. Boys were asked to wear the monitors for 7 consecutive days, i. e. the whole week.

Assessment of health-related physical fitness was estimated by measuring the following components:

1) body composition (body weight, BMI, body fat mass in per cent and $\mathrm{kg}$, lean body mass) was accessed using TANITA Body Analyser (TBF-300);

2) flexibility (sit and reach test, Eurofitas, 2002),

3) explosive power (vertical jump was measured using a jump parameter gauge (SBM-1),

4) muscular strength and endurance (modified push-up test, Suni et al., 1994).

Appropriate statistical methods (mean, (x) and the standard deviation (SD), one-way analysis of variance (ANOVA) and Pearson's correlation based upon the research design were applied. 
A significance level of 0.05 was used. Statistical analysis was carried out using SPSS 14.0 package for Windows.

\section{RESEARCH RESULTS}

All of the schoolboys experienced LPA on each day of the assessment. MPA on each day was experienced by $59.6 \%$ of the boys. No participants had achieved VPA. The frequency of MPA and VPA experienced most often was 5-7 and 1-3 days per week, respectively. The total PA measured during the week was largely comprised by LPA, i. e. $79.8 \%$; MPA and VPA were 18.8 and $1.4 \%$, respectively. Results indicated that boys experiencing VPA 3 or more days/week had significantly lower BMI than those who experienced VPA on 1 day/week, not experiencing VPA at all during the week, or than those who experienced MPA 6 days/week $(\mathrm{p}<0.05)$ (Figure).

For the analysis of health related physical fitness components the participants were divided into the groups according to the frequency of experienced Vigorous PA during the week (Table 1) and the frequency of experienced Moderate PA during the week (Table 2). Results of body composition indicated that boys experiencing VPA had lower body fat mass and lower BMI compared to those who experienced only VPA and LPA $(\mathrm{p}<0.05)$. Body water level (\%), on the contrary, were higher in groups were the boys experienced vigorous PA compared to groups with no vigorous PA and moderate PA. Analysis of separate physical fitness results indicated that boys who experienced VPA were better in muscular strength and endurance test - modified push up test ( $p<0.05)$, but results of high jump and sit and reach test were not significantly different. Analysis of sit and reach test even showed that boys experiencing vigorous PA once a week demonstrated better results compared to those experiencing vigorous PA 2 times/ week $(p<0.05)$. However, statistical significant differences $(p>0.05)$, were not established, but a tendency was observed that boys experiencing moderate PA 7 days week had lower BMI and body fat content, and they demonstrated better results in sit and reach test $(p>0.05)$ (Table 2).

No significant correlation was found between total amount of PA, time spent for vigorous and moderate PA and health-related physical fitness components. Only high jump test results were closely related to body composition, weak significant correlations were found between BMI, body fat and body water $(\mathrm{r}=0.279-0.387 ; \mathrm{p}<0.05)$.

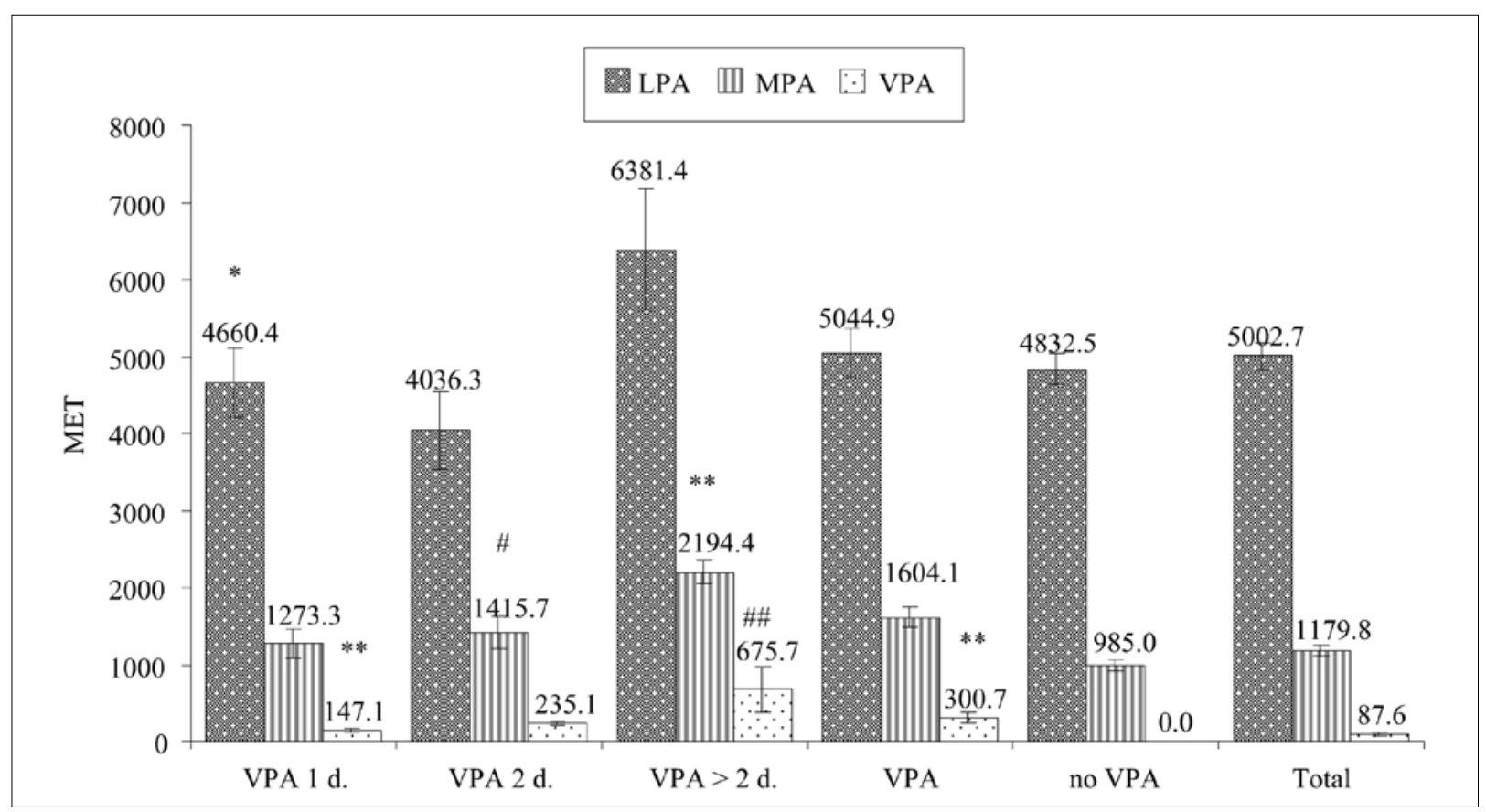

Note. ${ }^{*}-\mathrm{p}<0.05$ comparing with the groups of VPA experienced more than 2 days/week; ${ }^{* *}-\mathrm{p}<0.05$ comparing with all of the groups except VPA 2 days/week; \# - p $<0.05$ comparing with a group having experienced no VPA group; \#\# $-\mathrm{p}<0.05$ comparing with all groups. 


\begin{tabular}{|l|c|c|c|c|c|c|}
\hline \multicolumn{1}{|c|}{ Physical activity } & BMI & $\begin{array}{c}\text { FAT, } \\
\text { \% }\end{array}$ & $\begin{array}{c}\text { Body } \\
\text { water, \% }\end{array}$ & $\begin{array}{c}\text { High Jump, } \\
\mathbf{c m}\end{array}$ & $\begin{array}{c}\text { Sit and } \\
\text { reach, cm }\end{array}$ & $\begin{array}{c}\text { Push up, } \\
\text { n/40 s }\end{array}$ \\
\hline Vigorous PA 3 d. and $>$ & $18.2 \#$ & 7.7 & $67.4 * *$ & 37.9 & 19.9 & 18.2 \\
\hline Vigorous PA 2 d. & 20.6 & 11.0 & 65.2 & 36.8 & 14.8 & 16.9 \\
\hline Vigorous PA 1 d. & 22.0 & $14,65^{*}$ & 62,6 & 37.5 & $23,94^{* * *}$ & 16.9 \\
\hline Vigorous PA & 20.4 & 11.5 & 64.8 & 37.4 & 19.7 & $17.24^{* * *}$ \\
\hline no Vigorous PA & 21.5 & 12.6 & 64.0 & 38.4 & 20.1 & 18.9 \\
\hline
\end{tabular}

Table 1. Health-related physical fitness of the adolescent boys who experienced/did not experience vigorous PA

Note. ${ }^{*}-\mathrm{p}<0.05$, comparing with the groups of VPA experienced 3 days/week and more; $* *-p<0.05$, comparing with the groups of VPA experienced less than 1 days/week; $* * *-p<0.05$, comparing with the groups of MPA experienced more than 2 days/week; $\#-\mathrm{p}<0.05$, comparing with "VPA 1 day/week", "no VPA".

\begin{tabular}{|l|c|c|c|c|c|c|}
\hline \multicolumn{1}{|c|}{ Physical activity } & BMI & FAT, \% & $\begin{array}{c}\text { Body } \\
\text { water, \% }\end{array}$ & $\begin{array}{c}\text { High Jump, } \\
\text { cm }\end{array}$ & $\begin{array}{c}\text { Sit and } \\
\text { reach, cm }\end{array}$ & $\begin{array}{c}\text { Push up, } \\
\mathbf{n} / \mathbf{4 0 ~ s}\end{array}$ \\
\hline Moderate PA 7 d. & 20.8 & 11.9 & 64.5 & 38.1 & 20.8 & 18.2 \\
\hline Moderate PA 6 d. & 21.6 & 12.4 & 64.2 & 37.8 & 19.6 & 18.9 \\
\hline Moderate PA < 6 d. & 21.3 & 13.2 & 63.6 & 38.7 & 17.3 & 17.3 \\
\hline
\end{tabular}

Table 2. Health-related physical fitness of the adolescent boys who experienced/did not experience moderate PA

\section{DISCUSSION}

The purpose of this study was to estimate physical activity levels among 15-16-year-old adolescents by using objective measurement. Most of previous Lithuanian adolescents' physical activity data were largely based on questionnaires and interviews (Rutkauskaite et al., 2011). It was established that total amount of PA was 7622 MET's/week. In comparison with data based on subjective IPAQ questionnaire, the total amount of PA among adolescents was quite different (Rutkauskaite et al., 2011). Similar results were presented in HELENA study, where poor to fair correlations between the two methodologies were found for the whole study sample and were stratified by age and gender (Ottevaere et al., 2011).

The use of actigraphy helps accurately quantify not only the total amount of activity, but ideally register the amount of low, moderate, and vigorous habitual physical activity accrued during the daily life. It is well established that regular physical activity (PA) has many short- and long-term benefits for health (Katzmarzyk, Craig, 2006). Despite these benefits many children, adolescents and adults do not engage in recommended amounts of physical activity (Malina, Katzmarzyk, 2006; Samdal et al., 2007). In order to gain benefits for health, all activities have to be at least 10 min duration that can be added up. As optimal development for children and adolescents requires a full variety of exercise and sports, within or in addition to, the daily "minimal hour" activities carried out several times a week for at least 10 minutes, which increases bone strength, stimulates the cardio-vascular system, increases muscle strength, maintains flexibility and body composition (The National Guidelines on Physical Activity for Ireland, 2009). In our research boys experiencing VPA were better in muscular strength and endurance, but there were differences in power and flexibility results $(\mathrm{p}>0.05)$.

Decreased levels of PA in schoolchildren may be related to their physical fitness levels and number of children with overweight and obesity (Hills et al., 2011). Evidence exists that PA may be positively related with the changes in body composition parameters, which is mainly connected with the decrease of fat mass and increase of lean body mass, but not with the changes of body mass or BMI (Carrel et al., 2005). R. M. Malina and P. T. Katzmarzyk (2006) stated that mostly components of physical fitness change with growth and maturation independently of physical activity, and it is difficult to partition effects of activity from the expected changes. The relationships appear to be confounded to some degree by body fatness (Twisk et al., 2000; Hills et al., 2011) which indicates that physical activity may not provide complete protection from the health risks of obesity in children. As both physical activity and fitness have been found to be related over the lifespan 
(Twisk et al., 2000), it is important that children establish positive lifestyle habits and healthy levels of fitness at an early age.

Although overweight or obesity are not common among Lithuanian children yet, evidence exists that overweight in children prevails when acceleration rate is stabilized or even decreased (Jankauskiene, 2008). Results of our research showed that boys experiencing vigorous PA had lower body fat mass and lower BMI in comparison with those who experienced only VPA and LPA $(\mathrm{p}<0.05)$.

Findings from this study should be interpreted in light of several limitations. The sample size is small and requires replication with a larger sample. Additionally, while actigraphy is an objective measure of PA, it would be interesting to compare data from not objectively measured PA, e. g. questionnaires.

\section{CONCLUSIONS AND PERSPECTIVES}

Boys who achieve VPA have a greater total physical activity during the week than those boys who do not experience VPA. If during the week boys have VPA on more than 2 days, even if it is just for $10 \mathrm{~min}$, there is a significant increase in the total amount of weekly physical activity, which is related to lower fat mass. For boys who do not experience MPA at least for 6 days/week, the total amount of weekly physical activity decreases and they cannot produce better results in strength and endurance test $(p<0.05)$. Better results of boys' muscular strength and endurance were significantly related to lower BMI $(r=0.279 ; \mathrm{p}<0.05)$ and fat body mass $(r=0.387 ; p<0.01)$.

\section{REFERENCES}

Burdette, H. L., Whitaker, R. C. (2005). Resurrecting free play in young children: Looking beyond fitness and fatness to attention, affiliation, and affect. Archives of Paediatrics \& Adolescent Medicine, 159, 46-50.

Carrel, A. L., Clark, R. R., Peterson, S. E. et al. (2005). Improvement of fitness, body composition, and insulin sensitivity in overweight children in a school-based exercise program: A randomized controlled study. Archives of Paediatrics \& Adolescent Medicine, 159, 963-968.

Dencker, M., Andersen, L. B. (2008). Health related aspects of objectively measured daily physical activity in children. Journal of Clinical Physiology and Functional Imaging, 28, 133-144.

Dencker, M., Thorsson, O., Karlsson, M. K. et al. (2006). Daily physical activity and its relation to aerobic fitness in children aged 8-11 years. European Journal of Applied Physiology, 96 (5), 587-592.

Eurofitas. Fizinio pajegumo testai ir metodika, Lietuvos moksleiviu fizinio pajégumo rezultatai. (2002). Sud. V. Volbekienè. Vilnius: LSIC.

Hills, A. P., Andersen, L. B., Byrne, N. M. (2011). Physical activity and obesity in children. British Journal of Sports Medicine, 45 (11), 866-870.

Jankauskienè, R. (2008). Lietuvos gyventojų fizinio aktyvumo skatinimo strategija: kūno kultūra ar kūno kultas? Medicina (Kaunas), 44 (5), 345-355.

Katzmarzyk, P. T., Craig, C. L. (2006). Independent effects of waist circumference and physical activity on all-cause mortality in Canadian women. Applied Physiology, Nutrition, and Metabolism, 31 (3), 271-276.

Lobstein., T., Baur, L., Uauy, R. (2004). Obesity in children and young people: A crisis in public health. Obesity Reviews, 5 (1), 74-85.
Malina, R. M., Katzmarzyk, P. T. (2006). Physical activity and fitness in an international growth standard for preadolescent and adolescent children. Food and Nutrition Bulletin, 27, (4), 295-313.

Matton, L., Thomis, M., Wijndaele, K. et al. (2006). Tracking of physical fitness and physical activity from youth to adulthood in females. Medicine and Science in Sport and Exercise, 38 (6), 1114-1120.

Ortega, F. B., Artero, E. G., Ruiz, J. R. et al. (2008). Reliability of health-related physical fitness tests in European adolescents. The HELENA Study. Reliability of fitness assessment in adolescents. International Journal of Obesity, 32, 49-57.

Ottevaere, C., Huybrechts, I., de Bourdeaudhuij, I. et al. (2011). Comparison of the IPAQ-A and Actigraph in relation to $\mathrm{VO}_{2}$ max among European adolescents: The HELENA study. Journal of Science and Medicine in Sport, 14, 317-324.

Rankinen, T., Bouchard, C. (2002). Genetics and blood pressure response to exercise, and its interactions with adiposity. A review. Preventative Cardiology, 5, 138-144.

Rutkauskaite, R., Emeljanovas, A., Volbekienè, V. et al. (2011). Relationship between physical activity and health-related physical fitness in 16-year-old boys. Ugdymas. Kūno kultūra. Sportas, 1 (80), 56-62.

Samdal, O., Tynjälä, J., Roberts, C. et al. (2007). Trends in vigorous physical activity and TV watching of adolescents from 1986 to 2002 in seven European Countries. European Journal of Public Health, 17, 242-248.

Sirard, J. R., Pate, R. R. (2001). Physical activity assessment in children and adolescents. Sports Medicine, 31, 439-454. 
Suni, J., Oja P., Laukkanen, R. et al. (1994). Test Manual for the Assessment of Health Related Fitness. Finland, Tampere: President Urko Kaleva Kekkonen Institute for Health Promotion Research.

The National Guidelines on Physical Activity for Ireland. (2009). Department of Health and Children, Health Service Executive.
Trost, S. G. (2001). Objective measurement of physical activity in youth: Current issues, future directions. Exercise and Sport Science Review, 29, 6-32.

Twisk, J. W., Kemper, H. C., Mechelen, W. (2000). Tracking of activity and fitness and the relationship with cardiovascular disease risk factors. Medicine and Science in Sports and Exercise, 32, 1455-1461.

\title{
OBJEKTYVIAI NUSTATYTAS PAAUGLIŲ BERNIUKŲ SAVAITINIS FIZINIS AKTYVUMAS IR JO SĄSAJOS SU SVEIKATA SUSIJUSIU FIZINIU PAJE்GUMU
}

\author{
Edita Maciulevičienė, Rita Sadzevičienė, Renata Rutkauskaitė \\ Lietuvos sporto universitetas, Kaunas, Lietuva
}

\begin{abstract}
SANTRAUKA
Tyrimo pagrindimas ir hipotezė. Objektyvūs fizinio aktyvumo (FA) nustatymo metodai pasaulyje plačiai naudojami, tačiau Lietuvoje tokio pobūdžio metodika taikoma itin retai. Taigi buvo atliktas bandomasis tyrimas objektyviai nustatant berniukų FA ir norint pradèti plètoti tikslesnę FA nustatymo metodiką Lietuvoje.

Tikslas - išanalizuoti paauglių berniukų objektyviai nustatytą savaitinį fizini aktyvumą ir jo sąsajas su sveikata susijusiu fiziniu pajègumu.

Metodai. Buvo tiriami 104 sveiki paaugliai berniukai. Mokiniu FA nustatytas naudojant Tri-axis ActiTrainer Activity Monitor prietaisus. Berniuku prašyta prietaisus nešioti savaitę. Jie privalëjo fiksuoti fizinę veiklą kas minutę. Analizuojant fizinio aktyvumo duomenis FA standartizuotas pagal energijos suvartojimą, t. y. intensyvumo lygius. Remiantis tyrimo metu naudojamo fizinio aktyvumo prietaiso (Tri-axis ActiTrainer Activity Monitor) rekomendacijomis, analizuojant duomenis naudotos tokios MET'u reikšmès: mažas FA (MFA) - iki 3 MET'ų, vidutinis (VFA) - 3-6 MET'os ir didelis (DFA) - 8 ir daugiau MET'u. Tiriamieji buvo suskirstyti i FA grupes pagal patiriamą didelio ir vidutinio FA dažni per savaitę. Su sveikata susijęs fizinis pajègumas nustatytas matuojant kūno kompoziciją (TANITA Body Analyser, TBF-300 prietaisu), lankstumą (,Sėstis-siekti“ testu - Eurofitas, 2002), staigiają jègą (SBM-1 prietaisu), raumenų jègą ir ištvermę (Modifikuotu atsispaudimų testu - Suni et al., 1994).

Rezultatai. Visi tirti berniukai patiria MFA kiekvieną dieną, VFA - 59,6\% tiriamuju, o DFA kasdien patiriančiu nenustatyta. Tiriamieji patiria VFA dažniausiai 5-7 dienas per savaitę, DFA - dažniausiai nuo 1 iki 3 dienų per savaitę. Kūno kompozicijos duomenų analizè parodè, kad berniukai, patiriantys DFA, turèjo mažesnį kūno riebalinio audinio kieki (\%), lyginant su patiriančiais tik VFA ir MFA. DFA patiriantys berniukai demonstravo geresnius raumenu jègos ir ištvermès rezultatus $(\mathrm{p}<0,05)$, tačiau staigiosios jègos ir lankstumo testų rezultatai statistiškai reikšmingai nesiskyrè.

Aptarimas ir išvados. DFA patiriančiu berniuku raumenu jègos ir ištvermès rezultatai buvo geresni ir jie turèjo mažesni kūno riebalinio audinio kieki $(\mathrm{p}<0,05)$. Berniukai, nepatiriantys VFA mažiausiai šešis k./sav., tuo pačiu sumažina bendrają FA apimti, jų raumenu jègos ir ištvermès rezultatai prastesni. Geresni raumenų jègos ir ištvermès rezultatai statistiškai reikšmingai susiję su mažesniu KMI $(r=0,279 ; p<0,05)$ bei riebalinio audinio kiekiu $(\mathrm{r}=0,387 ; \mathrm{p}<0,01)$.
\end{abstract}

Raktažodžiai: fizinè veikla, metos, aktigrafai. 